Jacek Kulicki

\title{
Ocena zasad opodatkowania podatkiem od nieruchomości gruntów, budynków i budowli należących do spółdzielni mieszkaniowej ${ }^{1}$
}

\author{
Assessment of the principles of real estate tax on land, buildings and \\ structures belonging to a housing cooperative
}

A housing cooperative that owns a real estate or a construction object and a perpetual usufructuary of land is a taxpayer regarding the real estate tax, except that it is paid according to different rates. In case of land and buildings related to business operations, the tax is calculated at higher rates. In the author's opinion, the statutory phrase "buildings related to conducting business activities" should be understood as a fact of an actual use of a residential building for such activities. Keywords: tax, premise, housing cooperative

Spółdzielnia mieszkaniowa będąca właścicielem nieruchomości lub obiektów budowlanych oraz użytkownikiem wieczystym gruntów jest podatnikiem podatku od nieruchomości, z tym że podatek ten opłacany jest według różnych stawek. W przypadku gruntów i budynków związanych z prowadzeniem działalności gospodarczej podatek wyliczany jest według wyższych stawek. W ocenie autora przez ustawowy zwrot „budynki związane z prowadzeniem działalności gospodarczej" należy rozumieć okoliczność polegającą na faktycznym wykorzystywaniu części budynku mieszkalnego na prowadzenie takiej działalności.

Słowa kluczowe: podatek, lokal, spółdzielnia mieszkaniowa

Doktor nauk prawnych, ekspert ds. finansów publicznych Biura Analiz Sejmowych • Kancelaria Sejmu, Wydział Analiz Społecznych i Ekonomicznych, Zespół Studiów Ekonomicznych, WARSZAWA, POLSKA • jacek.kulicki@sejm.gov.pl • https://orcid.org/0000-0003-2631-6428

\section{Przedmiot opinii}

Przedmiotem opinii jest odpowiedź na następujące pytania:

- „czy - w świetle obowiązujących przepisów - nieruchomości należące do spółdzielni mieszkaniowej, związane z działalnością gospodarczą, podlegają opodatkowaniu podatkiem od nieruchomości?",

1 Opinia prawna na temat zasad opodatkowania podatkiem od nieruchomości gruntów, budynków i budowli należących do spółdzielni mieszkaniowej sporządzona 8 sierpnia 2019 r. na zlecenie posła Klubu Parlamentarnego Platforma Obywatelska - Koalicja Obywatelska; BAS-WASiE 1636/19. 
- „czy powyższy stan rzeczy odnosi się również do nieruchomości, które służą obsłudze lokali mieszkalnych, tak należących do spółdzielców, jak i wynajmowanych na cele mieszkaniowe przez najemców, czy również tych posiadanych przez spółdzielnię, które służą zaspokojeniu potrzeb mieszkaniowych oraz innych potrzeb (m.in. lokale restauracyjne, sklepy, działki rekreacyjne)?”.

\section{Analiza kwestii sformułowanych w pytaniach}

Obowiązek podatkowy w podatku od nieruchomości kształtuje ustawa z 12 stycznia 1991 r. o podatkach i opłatach lokalnych (t.j. Dz.U. 2019, poz. 1170, ze zm.; dalej: u.p.lok.).

Zgodnie $\mathrm{z}$ art. 2 ust. 1 u.p.lok. opodatkowaniu tym podatkiem podlegają grunty (pkt 1), budynki lub ich części (pkt 2) oraz budowle lub ich części związane $\mathrm{z}$ prowadzeniem działalności gospodarczej (pkt 3).

Zgodnie $\mathrm{z}$ art. 3 ust. 1 u.p.lok. podatnikami tego podatku są osoby fizyczne, osoby prawne oraz jednostki organizacyjne nieposiadające osobowości prawnej, będące ${ }^{2}$ :

- właścicielami nieruchomości lub obiektów budowlanych ${ }^{3}$,

- posiadaczami samoistnymi nieruchomości lub obiektów budowlanych,

- użytkownikami wieczystymi gruntów.

Jeżeli nieruchomość lub obiekt budowlany stanowi współwłasność lub znajduje się w posiadaniu dwóch lub więcej podmiotów, to - zgodnie z art. 3 ust. 4 u.p.lok. - stanowi odrębny przedmiot opodatkowania, a obowiązek podatkowy od nieruchomości lub obiektu budowlanego ciąży (z pewnymi zastrzeżeniami,

2 Poza wymienionymi przypadkami obowiązek podatkowy ciąży również na podmiotach będących posiadaczami nieruchomości lub ich części albo obiektów budowlanych lub ich części, stanowiących własność Skarbu Państwa lub jednostki samorządu terytorialnego, jeżeli posiadanie: a) wynika z umowy zawartej z właścicielem, Krajowym Ośrodkiem Wsparcia Rolnictwa lub z innego tytułu prawnego, z wyjątkiem posiadania przez osoby fizyczne lokali mieszkalnych niestanowiących odrębnych nieruchomości, b) jest bez tytułu prawnego. Zgodnie z art. 3 ust. 2 u.p.lok. obowiązek podatkowy dotyczący w tym przypadku przedmiotów opodatkowania wchodzących w skład Zasobu Własności Rolnej Skarbu Państwa lub będących w zarządzie Państwowego Gospodarstwa Leśnego Lasy Państwowe ciąży odpowiednio na jednostkach organizacyjnych Krajowego Ośrodka Wsparcia Rolnictwa i jednostkach organizacyjnych Lasów Państwowych, faktycznie władających nieruchomościami lub obiektami budowlanymi.

3 Zgodnie $\mathrm{z}$ art. 3 ust. 3 u.p.lok. w związku z art. 3 ust. 1 pkt 1 u.p.lok., jeżeli przedmiot opodatkowania znajduje się w posiadaniu samoistnym, obowiązek podatkowy w zakresie podatku od nieruchomości ciąży na posiadaczu samoistnym. 
zob. art. 3 ust. 4a-6 u.p.lok.) solidarnie na wszystkich współwłaścicielach lub posiadaczach.

Jeśli wyodrębniono własność lokali, obowiązek podatkowy w zakresie podatku od nieruchomości od gruntu oraz od części budynku stanowiących nieruchomość wspólną w rozumieniu art. 3 ustawy o własności lokali ${ }^{4}$ ciąży na właścicielach w zakresie odpowiadającym ich udziałowi w nieruchomości wspólnej (art. 3 ust. 5 u.p.lok.).

Podstawę opodatkowania podatkiem od nieruchomości stanowi:

- dla gruntów - powierzchnia (art. 4 ust. 1 pkt 1 u.p.lok.),

- dla budynków lub ich części - powierzchnia użytkowa (art. 4 ust. 1 pkt 2 i ust. 2 u.p.lok.),

- dla budowli lub ich części związanych z prowadzeniem działalności gospodarczej - wartość, o której mowa w przepisach o podatkach dochodowych ${ }^{5}$, ustalona na dzień 1 stycznia roku podatkowego, stanowiąca podstawę obliczania amortyzacji w tym roku, niepomniejszona o odpisy amortyzacyjne, a w przypadku budowli całkowicie zamortyzowanych - ich wartość z dnia 1 stycznia roku, w którym dokonano ostatniego odpisu amortyzacyjnego (art. 4 ust. 1 pkt 3 i ust. $4-9$ u.p.lok.).

Stawki podatku od nieruchomości określa w drodze uchwały rada gminy, przy czym stawki te nie mogą być wyższe od stawek maksymalnych wynikających $\mathrm{z}$ art. 5 ust. 1 u.p.lok.

Zgodnie $\mathrm{z}$ art. 1a ust. 1 u.p.lok. ustawodawca dla celów podatku od nieruchomości uznaje za:

4 Ustawa z 24 czerwca 1994 r., t.j. Dz.U. 2019, poz. 737. Zgodnie z art. 3 ust. 1 tej ustawy w razie wyodrębnienia własności lokali właścicielowi lokalu przysługuje udział w nieruchomości wspólnej jako prawo związane z własnością lokali, przy czym nie można żądać zniesienia współwłasności nieruchomości wspólnej, dopóki trwa odrębna własność lokali. Nieruchomość wspólną stanowi grunt oraz części budynku i urządzenia, które nie służą wyłącznie do użytku właścicieli lokali (zob. art. 3 ust. 2), zaś udział właściciela lokalu wyodrębnionego w nieruchomości wspólnej odpowiada stosunkowi powierzchni użytkowej lokalu wraz z powierzchnią pomieszczeń przynależnych do łącznej powierzchni użytkowej wszystkich lokali wraz z pomieszczeniami do nich przynależnymi (art. 3 ust. 3). Jeżeli nieruchomość, z której wyodrębnia się własność lokali, stanowi grunt zabudowany kilkoma budynkami, udział właściciela lokalu wyodrębnionego w nieruchomości wspólnej odpowiada stosunkowi powierzchni użytkowej lokalu wraz z powierzchnią pomieszczeń przynależnych do łącznej powierzchni użytkowej wszystkich lokali wraz z pomieszczeniami do nich przynależnymi (art. 3 ust. 5).

5 Zob. art. 16g ustawy z 15 lutego 1992 r. o podatku dochodowym od osób prawnych (t.j. Dz.U. 2019, poz. 865, ze zm.) oraz art. 22g ustawy z 26 lipca 1991 r. o podatku dochodowym od osób fizycznych (t.j. Dz.U. 2018, poz. 1509, ze zm.). 
- budynek - obiekt budowlany w rozumieniu przepisów prawa budowlanego ${ }^{6}$, który jest trwale związany z gruntem, wydzielony z przestrzeni za pomocą przegród budowlanych oraz posiada fundamenty i dach (pkt 1),

- budowlę - obiekt budowlany w rozumieniu przepisów prawa budowlanego niebędący budynkiem lub obiektem małej architektury, a także urządzenie budowlane $\mathrm{w}$ rozumieniu przepisów prawa budowlanego związane $\mathrm{z}$ obiektem budowlanym, które zapewnia możliwość użytkowania obiektu zgodnie z jego przeznaczeniem (pkt 2) ${ }^{7}$,

- grunty, budynki i budowle związane z prowadzeniem działalności gospodarczej - grunty, budynki i budowle będące w posiadaniu przedsiębiorcy lub innego podmiotu prowadzącego działalność gospodarczą (pkt 3), z tym że zgodnie z art. 1a ust. 2a pkt 1 u.p.lok. - nie zalicza się do nich m.in. budynków mieszkalnych oraz gruntów związanych z tymi budynkami,

- działalność gospodarczą - działalność, o której mowa w ustawie z 6 marca 2018 r. - Prawo przedsiębiorców (t.j. Dz.U. 2019, poz. 1292) ${ }^{8}$, z tym że za działalność gospodarczą w rozumieniu ustawy o podatkach i opłatach lokalnych nie uważa się: a) działalności rolniczej lub leśnej, b) wynajmu turystom pokoi gościnnych w budynkach mieszkalnych znajdujących się na obszarach wiejskich przez osoby ze stałym miejscem pobytu w gminie położonej na tym terenie, jeżeli liczba pokoi przeznaczonych do wynajęcia nie przekracza 5, c)

$6 \quad$ Ustawa z 7 lipca 1994 r. - Prawo budowlane, t.j. Dz.U. 2019, poz. 1186, ze zm.

7 Zgodnie z art. 3 pkt 3 ustawy - Prawo budowlane za budowlę uznawany jest każdy obiekt budowlany niebędący budynkiem lub obiektem małej architektury, jak: obiekty liniowe, lotniska, mosty, wiadukty, estakady, tunele, przepusty, sieci techniczne, wolno stojące maszty antenowe, wolno stojące trwale związane $\mathrm{z}$ gruntem tablice reklamowe i urządzenia reklamowe, budowle ziemne, obronne (fortyfikacje), ochronne, hydrotechniczne, zbiorniki, wolno stojące instalacje przemysłowe lub urządzenia techniczne, oczyszczalnie ścieków, składowiska odpadów, stacje uzdatniania wody, konstrukcje oporowe, nadziemne i podziemne przejścia dla pieszych, sieci uzbrojenia terenu, budowle sportowe, cmentarze, pomniki, a także części budowlane urządzeń technicznych (kotłów, pieców przemysłowych, elektrowni jądrowych, elektrowni wiatrowych i innych urządzeń) oraz fundamenty pod maszyny i urządzenia jako odrębne pod względem technicznym części przedmiotów składających się na całość użytkową. Zgodnie z art. 3 pkt 3a ustawy - Prawo budowlane obiektem liniowym jest obiekt budowlany, którego charakterystycznym parametrem jest długość, w szczególności droga wraz ze zjazdami, linia kolejowa, wodociąg, kanał, gazociąg, ciepłociąg, rurociąg, linia i trakcja elektroenergetyczna, linia kablowa nadziemna i, umieszczona bezpośrednio w ziemi, podziemna, wał przeciwpowodziowy oraz kanalizacja kablowa, przy czym kable w niej zainstalowane nie stanowią obiektu budowlanego lub jego części ani urządzenia budowlanego.

8 Zgodnie z art. 3 ustawy - Prawo przedsiębiorców działalnością gospodarczą jest zorganizowana działalność zarobkowa, wykonywana we własnym imieniu i w sposób ciągły. 
sprzedaży przetworzonych w sposób inny niż przemysłowy produktów roślinnych lub zwierzęcych $\mathrm{w}$ warunkach określonych $\mathrm{w}$ art. 20 ust. 1c ustawy o podatku dochodowym od osób fizycznych.

Jak wynika z przywołanych przepisów obowiązek podatkowy w podatku od nieruchomości ciąży na każdej osobie fizycznej, osobie prawnej lub jednostce organizacyjnej nieposiadającej osobowości prawnej będącej właścicielem lub posiadaczem samoistnym nieruchomości lub obiektów budowlanych, użytkownikiem wieczystym gruntów lub posiadaczem nieruchomości lub ich części albo obiektów budowlanych lub ich części, stanowiących własność Skarbu Państwa lub jednostki samorządu terytorialnego w warunkach określonych w art. 3 ust. 1 pkt 4 u.p.lok.

Zgodnie z art. $1 \$ 1$ ustawy z 16 września 1982 r. - Prawo spółdzielcze (t.j. Dz.U. 2018, poz. 1285, ze zm.; dalej: u.pr.sp.), spółdzielnia jest dobrowolnym zrzeszeniem nieograniczonej liczby osób, o zmiennym składzie osobowym i zmiennym funduszu udziałowym, które w interesie swoich członków prowadzi wspólną działalność gospodarczą. Jednocześnie, zgodnie z art. $1 \S 2$ tej ustawy spółdzielnia może prowadzić działalność społeczną i oświatowo-kulturalną na rzecz swoich członków i ich środowiska.

Zgodnie z art. $11 \S 1$ u.pr. sp. spółdzielnia nabywa osobowość prawną z chwilą wpisania jej do Krajowego Rejestru Sądowego.

Spółdzielnie należą więc do osób prawnych, na których ciąży obowiązek podatkowy w podatku od nieruchomości w zakresie określonym w ustawie o podatkach i opłatach lokalnych, prowadzących działalność gospodarczą na podstawie ustawy - Prawo spółdzielcze, innych ustaw i zarejestrowanego statutu.

Do spółdzielni mieszkaniowych zastosowanie mają - obok Prawa spółdzielczego - przepisy ustawy z 15 grudnia 2000 r. o spółdzielniach mieszkaniowych (t.j. Dz.U. 2018, poz. 845, ze zm.; dalej: u.sp.m.).

Celem spółdzielni mieszkaniowej jest zaspokajanie potrzeb mieszkaniowych i innych potrzeb członków oraz ich rodzin, przez dostarczanie członkom samodzielnych lokali mieszkalnych lub domów jednorodzinnych, a także lokali o innym przeznaczeniu (art. 1 ust. 1 u.sp.m.). Przedmiotem działalności spółdzielni mieszkaniowej może być (art. 1 ust. 2 u.sp.m.):

- budowanie lub nabywanie budynków w celu ustanowienia na rzecz członków spółdzielczych lokatorskich praw do znajdujących się w tych budynkach lokali mieszkalnych,

- budowanie lub nabywanie budynków w celu ustanowienia na rzecz członków odrębnej własności znajdujących się w tych budynkach lokali mieszkalnych lub lokali o innym przeznaczeniu, a także ułamkowego udziału we współwłasności w garażach wielostanowiskowych,

- budowanie lub nabywanie domów jednorodzinnych w celu przeniesienia na rzecz członków własności tych domów, 
- udzielanie pomocy członkom w budowie przez nich budynków mieszkalnych lub domów jednorodzinnych,

- budowanie lub nabywanie budynków w celu wynajmowania lub sprzedaży znajdujących się w tych budynkach lokali mieszkalnych lub lokali o innym przeznaczeniu.

Zgodnie z art. 1 ust. 3 u.sp.m. spółdzielnia ma obowiązek zarządzania nieruchomościami stanowiącymi jej mienie lub nabyte na podstawie ustawy mienie jej członków. Co istotne, statut spółdzielni określa, którą działalność spośród tych działalności (wymienionych przez ustawodawcę w art. 1 ust. 2 i 3 u.sp.m.) prowadzi spółdzielnia.

Spółdzielnia może również zarządzać nieruchomością niestanowiącą jej mienia lub mienia jej członków na podstawie umowy zawartej z właścicielem (współwłaścicielami) tej nieruchomości (art. 1 ust. 5 u.sp.m.). Może także prowadzić inną działalność gospodarczą na zasadach określonych w odrębnych przepisach i w statucie, jeżeli działalność ta związana jest bezpośrednio z realizacją celu założenia spółdzielni mieszkaniowej, a więc zaspokajania potrzeb mieszkaniowych i innych potrzeb członków oraz ich rodzin, przez dostarczanie członkom samodzielnych lokali mieszkalnych lub domów jednorodzinnych, a także lokali o innym przeznaczeniu (art. 1 ust. 6 u.sp.m.).

Analiza przywołanych przepisów Prawa spółdzielczego i ustawy o spółdzielniach mieszkaniowych wskazuje jednoznacznie, że spółdzielnia mieszkaniowa jest dobrowolnym zrzeszeniem nieograniczonej liczby osób, o zmiennym składzie osobowym i zmiennym funduszu udziałowym, które w interesie swoich członków prowadzi wspólną działalność gospodarczą, której celem jest zaspokajanie potrzeb mieszkaniowych i innych potrzeb członków oraz ich rodzin, przez dostarczanie członkom samodzielnych lokali mieszkalnych lub domów jednorodzinnych, a także lokali o innym przeznaczeniu (art. $1 \$ 1$ u.pr.sp. i art. 1 ust. 1 u.sp.m.). Przedmiotem tej działalności może być zarówno budowa, jak i nabywanie budynków w celach wskazanych w art. 1 ust. 2 u.sp.m., zarządzanie nieruchomościami stanowiącymi jej mienie lub nabytym na podstawie ustawy mieniem jej członków (art. 1 ust. 3 u.sp.m.), jak też zarządzanie nieruchomością niestanowiącą jej mienia lub mienia jej członków (art. 1 ust. 5 u.sp.m.) oraz prowadzenie innej działalności gospodarczej (art. 1 ust. 6 u.sp.m.). Spółdzielnia może również prowadzić działalność społeczną i oświatowo-kulturalną na rzecz swoich członków i ich środowiska (art. $1 \$ 2$ u.pr.sp.).

Spółdzielnia mieszkaniowa jest więc podmiotem prowadzącym działalność gospodarczą, co nie powinno budzić wątpliwości w świetle przytoczonych regulacji prawnych oraz orzecznictwa sądowego9.

9 Zob. m.in. również uchwały: SN z 11 lipca 2014 r., sygn. akt III CZP 33/14, http://www. sn.pl/sites/orzecznictwo/Orzeczenia3/III\%20CZP\%2033-14.pdf [dostęp 2 sierpnia 
Działalność gospodarczą spółdzielni mieszkaniowych różnicować można według różnych kryteriów, wyróżniając działalność skierowaną do członków i ich rodzin (na zaspokajanie ich potrzeb) i podmiotów zewnętrznych, działalność obligatoryjną (np. zarządzanie nieruchomościami stanowiącymi jej mienie lub nabytym na podstawie ustawy mieniem jej członków) i fakultatywną (np. zarządzanie nieruchomością niestanowiącą jej mienia lub mienia jej członków), czy też inwestycyjną (budowa lub nabywanie budynków) i związaną z bieżącym zarządzaniem mieniem spółdzielni i jej członków oraz dotyczącą budynków mieszkalnych i gruntów związanych z tymi budynkami i pozostałych budynków, budowli i gruntów.

W każdym przypadku spółdzielnia mieszkaniowa będąca właścicielem lub posiadaczem samoistnym nieruchomości lub obiektów budowlanych oraz użytkownikiem wieczystym gruntów jest podatnikiem podatku od nieruchomości. Podatek ten opłacany jest jednak według różnych stawek, w zależności od tego, czy przedmiotem opodatkowania są budynki mieszkalne oraz grunty związane $\mathrm{z}$ tymi budynkami, o których mowa $\mathrm{w}$ art. 1a ust. 2a pkt 1 u.p.lok., czy też nieruchomości i budowle kwalifikowane są do gruntów, budynków i budowli związanych $\mathrm{z}$ prowadzeniem działalności gospodarczej, zgodnie $\mathrm{z}$ art. 1a ust. 1 pkt 3 u.p.lok.

W pierwszym przypadku - budynków mieszkalnych oraz gruntów związanych z tymi budynkami - podatek opłacany jest według stawek wynikających $\mathrm{z}$ art. 5 ust. 1 pkt 1 lit. $\mathrm{c}$ u.p.lok. ${ }^{10}$, a więc dla gruntów pozostałych (w przypadku gruntów) oraz z art. 5 ust. 1 pkt 2 lit. a u.p.lok. ${ }^{11}$, a więc dla budynków mieszkalnych (w przypadku budynków mieszkalnych lub ich części) lub art. 5 ust. 1 pkt 2 lit. e u.p.lok. ${ }^{12}$, a więc dla budynków pozostałych (w przypadku części niemieszkalnych budynku mieszkalnego wielorodzinnego, stanowiących przedmiot odrębnej własności ${ }^{13}$.

W drugim przypadku - gruntów, budynków i budowli związanych z prowadzeniem działalności gospodarczej - podatek opłacany jest według stawek wyni-

2019 r.] oraz NSA z 27 lutego 2012 r., sygn. akt II FPS 4/11, http://orzeczenia.nsa.gov. $\mathrm{pl} /$ cbo/query [dostęp 2 sierpnia $2019 \mathrm{r}$.].

10 Obecnie maksymalna stawka nie może przekroczyć 0,49 zł od $1 \mathrm{~m}^{2}$. Zob. pkt 1 lit. a tiret trzecie obwieszczenia Ministra Finansów z 25 lipca 2018 r. w sprawie górnych granic stawek kwotowych podatków i opłat lokalnych na rok 2019 (MP poz. 745; dalej: ob.MF).

11 Obecnie maksymalna stawka nie może przekroczyć 0,79 zł od $1 \mathrm{~m}^{2}$, pkt 1 lit. b tiret pierwsze ob.MF.

12 Obecnie maksymalna stawka nie może przekroczyć 7,90 zł od $1 \mathrm{~m}^{2}$. Zob. pkt 1 lit. b tiret piąte ob.MF.

13 Zob. w odniesieniu do garaży uchwałę NSA z 27 lutego 2012 r., sygn. akt II FPS 4/11, http://orzeczenia.nsa.gov.pl/cbo/query [dostęp 2 sierpnia 2019 r.]. 
kających z art. 5 ust. 1 pkt 1 lit. a u.p.lok. ${ }^{14}$ (w przypadku gruntów), art. 5 ust. 1 pkt 2 lit. b u.p.lok. ${ }^{15}$ (w przypadku budynków niemieszkalnych oraz budynków mieszkalnych lub ich części zajętych na prowadzenie działalności gospodarczej) oraz art. 5 ust. 1 pkt 3 u.p.lok. ${ }^{16}$ (w przypadku budowli).

Jak wynika z ugruntowanej linii orzeczniczej sądów administracyjnych ustawowy zwrot „budynki związane z prowadzeniem działalności gospodarczej”: należy rozumieć jako okoliczność faktyczna polegajaca na rzeczywistym wykorzystywaniu (zajęciu) określonej części budynku mieszkalnego na prowadzenie działalności gospodarczej, tj. prowadzeniu w tej części budynku (np. w lokalu użytkowym) działalności gospodarczej w rozumieniu art. 1 a ust. 1 pkt 4 u.p.o.l. [ustawa o podatkach i opłatach lokalnych - dopisek J.K.] Za „zajęte na prowadzenie działalności gospodarczej" nie będa mogły być uznane natomiast te części budynku, które sa wykorzystywane (zajęte) na cele mieszkalne, nawet wówczas, gdy ich oddanie przez spółdzielnię (lub innego właściciela będącego przedsiębiorca) do korzystania osobom trzecim dla zaspokojenia ich potrzeb mieszkaniowych (zajęcie na cele mieszkalne), nastąiło w ramach gospodarczej działalności spółdzielni mieszkaniowej, jak również innego przedsiębiorcy (np. w drodze komercyjnego najmu lokalu mieszkalnego). [...] (Z) redakcji wskazanych unormowań nie wynika, by intencja ustawodawcy było objęcie powierzchni lokalu mieszkalnego (wykorzystywanego faktycznie tylko na cel mieszkalny) podatkiem przewidzianym dla budynków lub ich części związanych z prowadzeniem działalności gospodarczej, a to z tego powodu, że lokal taki został udostępniony członkowi spółdzielni mieszkaniowej, która obligatoryjnie zajmuje się jego zarządem, lub wynajęty najemcy przez podmiot prowadzacy działalność gospodarcza, polegająca na wynajmie lokali mieszkalnych. W konsekwencji zasadne staje się [...] stwierdzenie, że opodatkowanie będących w posiadaniu spółdzielni mieszkaniowej budynków, kwalifikowanych jako mieszkalne (jednorodzinne, dwurodzinne lub wielorodzinne), a to wedtug stawek podatku od nieruchomości właściwych dla budynków związanych z prowadzeniem działalności gospodarczej, uzależnione jest od tego, czy budynki te lub ich czesści zostały zajęte na prowadzenie działalności gospodarczej w przedstawionym wyżej rozumieniu. Stosowanie przy tym najwyższych stawek podatkowych dotyczy tylko zajętej na ten cel powierzchni użytkowej budynku mieszkalnego ${ }^{17}$.

14 Obecnie maksymalna stawka nie może przekroczyć $0,93 \mathrm{zł} \mathrm{od} 1 \mathrm{~m}^{2}$. Zob. pkt 1 lit. a tiret pierwsze ob.MF.

15 Obecnie maksymalna stawka nie może przekroczyć 23,47 zł od $1 \mathrm{~m}^{2}$. Zob. pkt 1 lit. b tiret drugie ob.MF.

16 Stawka podatku wynosi $2 \%$ wartości budowli przyjętej dla celów odpisów umorzeniowych w podatku dochodowym.

17 Wyrok WSA w Opolu z 16 listopada 2016 r., sygn. akt I SA/Op 370/16. Zob. również uchwałę NSA z 27 lutego 2012 r., sygn. akt II FPS 4/11, oraz wyroki NSA z: 15 stycznia 2013 r., sygn. akt II FSK 933/11; 18 grudnia 2013 r., sygn. akt II FSK 2767/11; 28 lipca 2016 r., sygn. akt II FSK 1795/14; 2 grudnia 2016 r., sygn. akt II FSK 3208/14; 
W orzecznictwie sądów administracyjnych ugruntowany jest również pogląd, że: przez grunty zwiąane $z$ budynkami mieszkalnymi należy rozumieć nie tylko grunty, na których taki obiekt budowlany został posadowiony, ale również grunty doń przylegające, zapewniające właściwe korzystanie z tego budynku, niezbędna obsługe budynku oraz jego mieszkańców, $w$ tym $w$ zakresie odpowiedniego skomunikowania, zabezpieczenia porzadku, rekreacji (np. chodniki, drogi dojazdowe, skwery, place dla dzieci) oraz zaspokojenia innych niezbędnych potrzeb zwiazanych z korzystaniem z powierzchni mieszkaniowej budynku ${ }^{18}$. Pojęcie "grunt związany” jest szersze niż „grunt pod.... Również WSA w Lublinie w wyroku z 3 grudnia 2008 r., sygn. akt I SA/Lu 529/08, stwierdził, że prawidłowa wykładnia art. 1a ust. 1 pkt 3 u.p.o.l. (obecnie art. 1a ust. 2 a pkt 1) nie pozwala utożsamiać „gruntów związanych z budynkami” z "gruntami pod budynkami” ${ }^{19}$. W powołanym już wyroku II FSK 933/11 NSA stwierdził, że: w przypadku wyodrębnienia $w$ wielorodzinnym budynku mieszkalnym samodzielnych lokali mieszkalnych, stanowiacych odrębne nieruchomości, w rozumieniu art. 2 ust. 1 i 2 ustawy z dnia 24 czerwca 1994 r. o własności lokali (Dz. U. z 2000 r. Nr 80, poz. 903 ze zm.), do lokali takich moga przynależeć, jako ich części składowe, pomieszczenia, choćby nawet do niego bezpośrednio nie przylegały lub były położone $w$ granicach nieruchomości gruntowej poza budynkiem, w którym wyodrębniono dany lokal, a w szczególności: piwnica, strych, komórka, garaż, zwane "pomieszczeniami przynależnymi” (art. 2 ust. 4 ustawy o własności lokali). Istotne jest, że podobne funkcje, tj. zwiazane z zaspokajaniem potrzeb mieszkaniowych, moga spetniać obiekty budowlane (zarówno obiekty małej architektury jak i budowle), położone w obrębie gruntów związanych z budynkiem mieszkalnym, a niestanowiące przynależności konkretnego lokalu mieszkalnego, lecz służace zaspokajaniu potrzeb mieszkaniowych ogółu mieszkańców budynku. Biorąc pod uwagę przedstawione rozważania, uwzględniające wykładnię systemowa polegająca na ustaleniu znaczenia przepisów prawnych ze względu na ich lokalizację $w$ strukturze źródeł prawa oraz powiazania, jakie występuja pomiędzy rozmaitymi aktami normatywnymi, Sąd w składzie rozpoznajacym te sprawe podziela pogląd wyrażony w powołanym już powyżej wyroku NSA $w$ sprawie II FSK 2420/13, aprobujacego w tym zakresie stanowisko zajęte wcześniej w wyroku II FSK 933/11, że opodatkowanie podatkiem od nieruchomości nie dotyczy też budowli zlokalizowanych na gruntach, które należy traktować jako związane z budynkami mieszkalnymi w przedstawionym wyżej znaczeniu, nawet

10 listopada 2015 r., sygn. akt II FSJK 2420/13, http://orzeczenia.nsa.gov.pl/cbo/query [dostęp 2 sierpnia 2019 r.]. Zob. także interpretacje indywidualne: Prezydenta Miasta Poznania z 23 listopada 2017 r. (nr 67), http://bip.poznan.pl/bip/podatek-od-nieruchomosci-osoby-prawne,p,14319,14320,14321.html [dostęp 2 sierpnia 2019 r.] oraz Prezydenta Miasta Gdańska z 9 maja 2017 r., nr WBMiP III.3120.2017.ZT, https:// www.gdansk.pl/download/2017-07/93174.pdf [dostęp 2 sierpnia 2019 r.].

18 Wyrok NSA z 15 stycznia 2013 r., sygn. akt II FSK 933/11.

19 Także wyrok NSA z 20 maja 2008 r., sygn. akt II FSK 425/07. 
jeżeli nie stanowią części składowej lokali mieszkalnych, ale których przeznaczenie wiąże się z realizacja potrzeb mieszkaniowych $i$ nie sa one wykorzystywane dla prowadzenia działalności gospodarczej. Takie też stanowisko zają WSA w Gliwicach w wyroku z 22 kwietnia 2013 r., sygn. akt I SA/Gl 982/12, uznając, że jeżeli budowla jest zlokalizowana na gruncie zwiąanym z budynkiem mieszkalnym, a przeznaczenie tej budowli wiąże się z realizacja potrzeb mieszkaniowych, to nie podlega ta budowla opodatkowaniu podatkiem od nieruchomości przewidzianym dla budowli związanych z prowadzeniem działalności gospodarczej, a określonej jako przedmiot podatku od nieruchomości $w$ art. 2 ust. 1 pkt 3 u.p.o.l. W kontekście regulacji zamieszczonej w art. 2 ust. 1 pkt 3 u.p.lok. oznacza to, że w ogóle nie podlega opodatkowaniu ${ }^{20}$.

Odpowiedzi na pytania

- (Odpowiedź na pytanie pierwsze) Nieruchomości należące do spółdzielni mieszkaniowej, związane z działalnością gospodarczą podlegają opodatkowaniu podatkiem od nieruchomości, z tym że do nieruchomości związanych z działalnością gospodarczą nie zalicza się budynków mieszkalnych oraz gruntów (wraz z posadowioną na nich infrastrukturą towarzyszącą) związanych z tymi budynkami, a więc grunty, na których taki obiekt budowlany został posadowiony, a także grunty doń przylegające, zapewniające właściwe korzystanie z tego budynku, niezbędną obsługę budynku oraz jego mieszkańców. W przypadku nieruchomości związanych z działalnością gospodarczą stosowane są wyższe stawki podatku od nieruchomości (wynikające w przypadku gruntów $-\mathrm{z}$ art. 5 ust. 1 pkt 1 lit. a u.p.lok., w przypadku budynków - z art. 5 ust. 1 pkt 2 lit. b, w przypadku budowli z - art. 5 ust. 1 pkt 3 u.p.lok.), zaś w przypadku budynków mieszkalnych oraz gruntów z nimi związanych niższe stawki podatku od nieruchomości (wynikające: w przypadku gruntów $\mathrm{z}$ art. 5 ust. 1 pkt 1 lit. c u.p.lok., w przypadku budynków mieszkalnych lub ich części - z art. 5 ust. 1 pkt 2 lit. a u.p.lok. lub art. 5 ust. 1 pkt 2 lit. e u.p.lok.);

- (odpowiedź na pytanie drugie) Opodatkowaniu podatkiem od nieruchomości podlegają również nieruchomości, które służa obsłudze lokali mieszkalnych, tak należących do spółdzielców, jak $i$ wynajmowanych $i$ wykorzystywanych na cele mieszkaniowe przez najemców, czy również tych posiadanych przez spótdzielnię, które służa zaspokajaniu potrzeb mieszkaniowych oraz innych potrzeb (m.in. lokale restauracyjne, sklepy, działki rekreacyjne), z tym że - podobnie jak w przypadku odpowiedzi na pytanie pierwsze - należy zauważyć, że inna stawka podatku (niższa) będzie w przypadku budynków mieszkalnych (ich części) oraz gruntów związanych z tymi budynkami (art. 5 ust. 1 pkt 1 lit. c, pkt 2 lit. a i e u.p.lok.), inna (wyższa) w przypadku lokali wynajmowanych na inne cele - działalność gospodarczą (art. 5 ust. 1 pkt 1 lit. a, pkt 2 lit. b i pkt 3 u.p.lok.).

20 Ibidem. 
Na zakończenie tej analizy warto również podnieść kwestię jednoznaczności obowiązujących przepisów ustawy o podatkach i opłatach lokalnych w zakresie opodatkowania budowli usytuowanych na gruntach związanych $\mathrm{z}$ budynkami mieszkalnymi. Zgodnie $\mathrm{z}$ art. 1a ust. 2a pkt 1 u.p.lok. do gruntów, budynków i budowli związanych z działalnością gospodarczą, a więc takich, od których podatek pobierany jest według wyższych stawek, nie zalicza się budynków mieszkalnych oraz gruntów związanych z tymi budynkami. W orzecznictwie administracyjnym pojawia się pogląd, biorący za podstawę wykładnię literalną (gramatyczną) przepisów podatkowych, że przepis ten (art. 1a ust. 2a pkt 1 u.p.lok.) wyłącza z kategorii gruntów, budynków i budowli związanych z działalnością gospodarczą jedynie budynki mieszkalne i grunty związane z tymi budynkami, nie wyłącza zaś budowli na takich gruntach posadowionych, co oznacza, że budowle takie traktowane są zawsze jako związane z działalnością gospodarczą i opodatkowane według stawek określonych dla działalności gospodarczejej (art. 5 ust. 1 pkt 3 u.p.lok.). Takiemu stanowisku sprzeciwia się orzecznictwo sądów administracyjnych, które uznaje, że w tym wypadku wykładnia gramatyczna nie pozwala na prawidłowe odczytanie normy prawnej i stwierdza, że: przez grunty związane z budynkami mieszkalnymi należy rozumieć nie tylko grunty, na których taki obiekt budowlany został posadowiony, ale również grunty doń przylegające, zapewniające wtaściwe korzystanie z tego budynku, niezbędna obstugę budynku oraz jego mieszkańców, $w$ tym $w$ zakresie odpowiedniego skomunikowania, zabezpieczenia porzadku, rekreacji (np. chodniki, drogi dojazdowe, skwery, place dla dzieci) oraz zaspokojenia innych niezbędnych potrzeb zwiazanych $z$ korzystaniem z powierzchni mieszkaniowej budynku ${ }^{22}$. W tym kontekście w części wyroków wskazuje się potrzebę interwencji ustawodawcy w kierunku zapewnienia większej jednoznaczności i określoności przedmiotu opodatkowania podatkiem od nieruchomości.

\section{Podsumowanie}

- W każdym wypadku spółdzielnia mieszkaniowa będąca właścicielem lub posiadaczem samoistnym nieruchomości lub obiektów budowlanych oraz użytkownikiem wieczystym gruntów jest podatnikiem podatku od nieruchomości, z tym że podatek ten opłacany jest według różnych stawek, w zależności od tego, czy przedmiotem opodatkowania są budynki mieszkalne oraz grunty zwią-

${ }^{21}$ Zob. np. przywołane już wcześniej: wyrok WSA w Opolu z 16 listopada 2016 r., sygn. akt I SA/Op 370/16, oraz interpretacje indywidualne: Prezydenta Miasta Poznania z 23 listopada 2017 r. (nr 67) i Prezydenta Miasta Gdańska z 9 maja 2017 r., nr WBMiP III.3120.2017.ZT.

22 Zob. przywołane wcześniej wyroki. 
zane z tymi budynkami, o których mowa w art. 1a ust. 2a pkt 1 u.p.lok., czy też nieruchomości i budowle kwalifikowane są do gruntów, budynków i budowli związanych z prowadzeniem działalności gospodarczej, zgodnie $\mathrm{z}$ art. 1a ust. 1 pkt 3 u.p.lok.

- W przypadku budynków mieszkalnych oraz gruntów związanych z tymi budynkami podatek opłacany jest według stawek niższych, wynikających z art. 5 ust. 1 pkt 1 lit. c, pkt 2 lit. a lub lit. e u.p.lok., zaś w przypadku gruntów, budynków i budowli związanych z prowadzeniem działalności gospodarczej podatek opłacany jest według stawek wyższych, wynikających $z$ art. 5 ust. 1 pkt 1 lit. a, pkt 2 lit. b i pkt 3 u.p.lok.

- Przez ustawowy zwrot „budynki związane z prowadzeniem działalności gospodarczej” należy - zgodnie z orzecznictwem sądowoadministracyjnym - rozumieć okoliczność faktyczną, polegającą na rzeczywistym wykorzystywaniu (zajęciu) określonej części budynku mieszkalnego na prowadzenie działalności gospodarczej, tj. prowadzeniu w tej części budynku (np. w lokalu użytkowym) działalności gospodarczej w rozumieniu art. 1a ust. 1 pkt 4 u.p.lok.

- W orzecznictwie sądów administracyjnych ugruntowany jest pogląd, że przez grunty związane z budynkami mieszkalnymi należy rozumieć nie tylko grunty, na których taki obiekt budowlany został posadowiony, ale również grunty doń przylegające, zapewniające właściwe korzystanie z tego budynku, niezbędną obsługę budynku oraz jego mieszkańców, w tym w zakresie odpowiedniego skomunikowania, zabezpieczenia porządku, rekreacji (np. chodniki, drogi dojazdowe, skwery, place dla dzieci) oraz zaspokojenia innych niezbędnych potrzeb związanych z korzystaniem z powierzchni mieszkaniowej budynku. 